\title{
Stability of Aseptically Prepared Tazocin Solutions in Polyvinyl Chloride Bags
}

\author{
Ronald F Donnelly
}

\begin{abstract}
Background: Tazocin, a mixture of piperacillin and tazobactam, has recently been reformulated to include edetate disodium (EDTA) and citric acid. Since the introduction of this new formulation, there have been no studies of stability in polyvinylchloride (PVC) bags.

Objective: To complete a physical compatibility and chemical stability study of the new formulation of Tazocin, prepared at 2 concentrations in each of 2 diluents and stored in PVC bags.

Methods: Tazocin, at 22.5 or $90 \mathrm{mg} / \mathrm{mL}$, was compounded in dextrose $5 \%$ in water (D5W) or $0.9 \%$ sodium chloride (normal saline [NS]) in PVC bags. The bags were stored at $5^{\circ} \mathrm{C}$ with protection from light for 14,21 , or 28 days, followed in each case by storage at $23^{\circ} \mathrm{C}$ with exposure to light for $72 \mathrm{~h}$. Triplicate samples collected at each of the 7 time points were analyzed in duplicate using a stability-indicating high-performance liquid chromatography method. Physical compatibility was determined by monitoring the solutions for changes in colour, clarity, and $\mathrm{pH}$.

Results: The amount of each drug remaining for each concentration in each diluent was above $95 \%$ of the initial concentration after storage at $5^{\circ} \mathrm{C}$ with protection from light and above $94 \%$ of the initial concentration after an additional $72 \mathrm{~h}$ at $23^{\circ} \mathrm{C}$ with exposure to light. The $\mathrm{pH}$ of the solutions changed only slightly over the course of the study, and all solutions remained clear and colourless.
\end{abstract}

Conclusions: Tazocin solutions at 22.5 and $90 \mathrm{mg} / \mathrm{mL}$, prepared in PVC bags of either D5W or NS, were chemically stable after storage for up to 28 days at $5^{\circ} \mathrm{C}$ with protection from light followed by $72 \mathrm{~h}$ at $23^{\circ} \mathrm{C}$ with exposure to light.

Key words: tazobactam, piperacillin, Tazocin, high-performance liquid chromatography, stability, polyvinylchloride bags

Can J Hosp Pharm 2009;62(3):226-231

\section{RÉSUMÉ}

Contexte : La Tazocine, un mélange de pipéracilline et de tazobactame, a récemment été modifiée pour inclure dans sa composition de l'acide éthylène diamine tétra acétique (EDTA) et de l'acide citrique. Depuis l'introduction de cette nouvelle composition, aucune étude de stabilité du mélange dans des sacs de polychlorure de vinyle (PVC) n'a été effectuée.

Objectif : Mener une étude de compatibilité physique et de stabilité chimique de solutions de la nouvelle composition de Tazocine préparées selon deux concentrations avec deux diluants et entreposées dans des sacs de PVC.

Méthodes : Des solutions de Tazocine à 22,5 at à $90 \mathrm{mg} / \mathrm{mL}$ ont été obtenues en la diluant dans du dextrose à $5 \%$ dans l'eau ou dans du chlorure de sodium à $0,9 \%$ (solution physiologique salée) dans des sacs de PVC. Les sacs ont été entreposés à une température de $5{ }^{\circ} \mathrm{C}$, protégés de la lumière, pendant 14,21 ou 28 jours, puis conservés à une température de $23{ }^{\circ} \mathrm{C}$ et exposés à la lumière pendant 72 heures. Les échantillons recueillis en triple à chacun des 7 points dans le temps ont été analysés en double à l'aide d'une épreuve validée par chromatographie liquide haute performance mesurant la stabilité. La compatibilité physique était évaluée en contrôlant tout changement dans la couleur, la limpidité et le $\mathrm{pH}$ des solutions.

Résultats : Les solutions aux deux concentrations dans les deux diluants ont retenu plus de $95 \%$ de leur concentration initiale de chaque médicament après avoir été conservées à une température de $5{ }^{\circ} \mathrm{C}$, protégées de la lumière, et plus de $94 \%$ de leurs concentrations initiales des deux médicaments après avoir été conservées pendant une période supplémentaire de 72 heures à une température de $23^{\circ} \mathrm{C}$ et exposées à la lumière. Le $\mathrm{pH}$ des solutions n'a que très peu changé au cours de l'étude, et toutes les solutions sont demeurées limpides et incolores.

Conclusions : Les solutions de Tazocine à 22,5 et à $90 \mathrm{mg} / \mathrm{mL}$, préparées dans des sacs de PVC et diluées dans du dextrose à $5 \%$ dans l'eau ou une solution physiologique salée, étaient chimiquement stables après avoir été entreposées pendant une période allant jusqu’à 28 jours à une température de $5^{\circ} \mathrm{C}$ et protégées de la lumière, et conservées pendant une période additionnelle de 72 heures à une température de $23^{\circ} \mathrm{C}$ et exposées à la lumière.

Mots clés : tazobactame, pipéracilline, Tazocine, chromatographie liquide haute performance, stabilité, sacs de polychlorure de vinyle

[Traduction par l'éditeur] 


\section{INTRODUCTION}

T azocin (Wyeth Canada) is a combination of a semisynthetic penicillin derivative, piperacillin sodium, and a B-lactamase inhibitor, tazobactam sodium, at a ratio of 8:1. This combination product has enhanced antibacterial activity against ß-lactamase-producing gram-positive and gramnegative aerobic and anaerobic bacteria. ${ }^{1}$

The stability of Tazocin has been studied for solutions in dextrose $5 \%$ in water (D5W) and normal saline (NS; $0.9 \%$ sodium chloride) in polyvinylchloride (PVC) bags. Moon and others ${ }^{2}$ reported that solutions of tazobactam $(10 \mathrm{mg} / \mathrm{mL})$ and piperacillin $(80 \mathrm{mg} / \mathrm{mL})$ in both D5W and NS were stable for 30 days when stored at $-15^{\circ} \mathrm{C}$. Hecq and others ${ }^{3}$ found that solutions of tazobactam $(4.4 \mathrm{mg} / \mathrm{mL})$ and piperacillin $(33.3 \mathrm{mg} / \mathrm{mL})$ in D5W retained above $90 \%$ of the initial concentration for 35 days when stored at $4^{\circ} \mathrm{C}$ after freezing and microwave thawing. Rigge and Jones ${ }^{4}$ reported that the combination of tazobactam $(5 \mathrm{mg} / \mathrm{mL})$ and piperacillin $(40 \mathrm{mg} / \mathrm{mL})$ in NS stored in PVC bags was stable for 5 days at $7^{\circ} \mathrm{C}$ and 4 days at $25^{\circ} \mathrm{C}$, irrespective of exposure to light. Stored in non-PVC bags, the NS solution was stable for 17 days at $7^{\circ} \mathrm{C}$ and 4 days at $25^{\circ} \mathrm{C}$ with protection from light. The duration of stability was further increased to 58 days at $7^{\circ} \mathrm{C}$ and 10 days at $25^{\circ} \mathrm{C}$ with protection from light when the Tazocin was prepared in a buffered NS solution and stored in non-PVC bags. The effect of tazobactam on the stability of piperacillin was studied by Mathew and others, ${ }^{5}$ who reported increased degradation of piperacillin when tazobactam was present in the formulation.

Tazocin has recently been reformulated to meet current USP (United States Pharmacopeia) standards for particulate matter. The formulation now includes edetate disodium (EDTA, a chelating agent) and sodium citrate (a buffer). The addition of these excipients lessens the possibility that particulate matter will accumulate during storage or upon reconstitution with commonly used diluents. It has also expanded the Y-site compatibility profile of Tazocin. ${ }^{6}$

Since the reformulation of Tazocin there have been no stability studies conducted in PVC bags. This study was therefore undertaken to provide physical compatibility and chemical stability data for solutions containing the reformulated Tazocin when diluted in either D5W or NS, packaged in PVC bags, and stored at $5^{\circ} \mathrm{C}$ with protection from light for 14,21 , and 28 days, with each of these storage periods followed by $72 \mathrm{~h}$ at $23^{\circ} \mathrm{C}$ with exposure to light.

\section{METHODS}

\section{Assay Validation}

The stability-indicating capability of the assay was validated for both tazobactam and piperacillin by chromatography of samples that had been forcibly degraded by the addition of an acidic or oxidizing agent at an elevated temperature. The acidic sample was prepared by adjusting the $\mathrm{pH}$ of $0.1 \mathrm{~mL}$ of Tazocin stock solution ( $2.25 \mathrm{~g}$ per $10 \mathrm{~mL})$, diluted to $10 \mathrm{~mL}$ with highperformance liquid chromatography (HPLC)-grade water, to about 2.0 with concentrated hydrochloric acid (BDH Inc, Toronto, Ontario; lot 120834-78180) and storing the solution at $23^{\circ} \mathrm{C}$. An oxidized sample was prepared by adding $0.15 \mathrm{~mL}$ of stabilized sodium hypochlorite ( $1 \%$ available chlorine, $\mathrm{pH}$ about 12) to $0.15 \mathrm{~mL}$ of Tazocin stock solution plus $9.7 \mathrm{~mL}$ of HPLC-grade water and was kept at $23^{\circ} \mathrm{C}$. A third sample of the solution, without addition of any other agent, was stored at $23^{\circ} \mathrm{C}$. A similar fourth sample was exposed to an elevated temperature $\left(40^{\circ} \mathrm{C}\right)$ in a hot water bath for $96 \mathrm{~h}$. Samples were taken from each solution periodically (at 5 time points) over $96 \mathrm{~h}$ and subjected to chromatography, to determine if there were any degradation peaks that would interfere with the parent peaks.

The linearity of the standard curve was determined over the concentration ranges of 0.625 to $3.75 \mathrm{mg} / \mathrm{mL}$ for tazobactam and 5.0 to $30.0 \mathrm{mg} / \mathrm{mL}$ for piperacillin. A stock solution of Tazocin was prepared by dissolving $119.0 \mathrm{mg}$ of lyophilized powder (Wyeth Canada Ltd, Saint Laurent, Quebec; 3.375-g vial, lot B83227, expiry October 2008) in $100 \mathrm{~mL}$ of HPLC-grade water and then further diluting to create the standard solutions. The reproducibility of the chromatographic method was measured by completing intraday ( 5 replicate injections at 3 different times) and interday analyses for each drug. Interday variance was determined by comparing slopes calculated from standard curves and the average area ratio (area of drug/area of internal standard) of the recovery samples on 5 separate days. The accuracy of the method was determined by analysis of recovery samples for each drug on 5 separate days. The sensitivity of the assay for each compound was also investigated. Peak purity analysis and chemical identification of both parent peaks were completed by ultraviolet (UV) multiwavelength analysis (at 220 and $210 \mathrm{~nm}$ ) and spectral overlay (at 200-350 nm). Relative standard deviation, resolution, and tailing factors were also determined.

\section{Stability Study}

To prepare a $100-\mathrm{mL}$ bag of Tazocin, either one $2.25-\mathrm{g}$ vial (22.5 mg/mL, Wyeth Canada, Saint-Laurent, Quebec; lot B68332, expiry May 2008) or two 4.5 -g vials $(90 \mathrm{mg} / \mathrm{mL}$, Wyeth Canada; lot B68627, expiry May 2008) were reconstituted according to the manufacturer's guidelines and shaken to dissolve. Contents of appropriate vial(s) were transferred into empty Viaflex PVC bags (Baxter Corp; lot ST06C48). Enough D5W (Baxter Corp, Mississauga, Ontario; lot W6K01A0, expiry May 2008) or NS (Baxter Corp; lot W6L22M1, expiry June 2008) was added to each bag to make up a volume of 
exactly $100 \mathrm{~mL}$ at a concentration of either $22.5 \mathrm{mg} / \mathrm{mL}$ (from a 2.25 -g vial) or $90 \mathrm{mg} / \mathrm{mL}$ (from two 4.5 -g vials). Four bags were prepared for each concentration- diluent combination, for a total of 16 bags.

\section{Sample Collection and Preparation}

Three samples ( $5 \mathrm{~mL}$ each) taken from one bag of each concentration-diluent combination were designated as day 0 samples. The rest of the bags were then stored at $5^{\circ} \mathrm{C}$ with protection from light. On days 14, 21, and 28, 3 additional samples of $5 \mathrm{~mL}$ each were removed from one bag of each concentration-diluent combination and analyzed. The bags from which the samples had been removed were then stored at $23^{\circ} \mathrm{C}$ with exposure to light for an additional $72 \mathrm{~h}$, after which an additional 3 samples were collected and analyzed. Samples containing $22.5 \mathrm{mg} / \mathrm{mL}$ of Tazocin were diluted 1:100 with mobile phase, whereas samples containing $90 \mathrm{mg} / \mathrm{mL}$ of Tazocin were diluted 1:400 with mobile phase; the samples were analyzed in duplicate for total $n=6$.

\section{Chromatographic Analysis}

Chemical assays were conducted using a modification of an unpublished HPLC method (Wyeth test method: Zosyn [EDTA formulation], method no. MZOSP026.00). The modifications were use of a $3-\mu \mathrm{m}, 4.6 \times 150 \mathrm{~mm}$ phenyl-hexyl column (Luna, Phenomenex Inc, Torrance, California; catalogue no. 00F-4256-E0, lot 365391-1) and adjustment of the $\mathrm{pH}$ of the mobile phase to 2.0 instead of 3.8. The HPLC system consisted of an isocratic pump (model LC-10AT, Shimadzu Corp, Tokyo, Japan), a photodiode array detector (model SDP-M6A, Shimadzu Corp) set at $220 \mathrm{~nm}$, and an autoinjector (model SIL-10AXL, Shimadzu Corp) that injected $20-\mu \mathrm{L}$ samples. The flow was set at $1.0 \mathrm{~mL} / \mathrm{min}$. Class-VP software (version 4.2, Shimadzu Corp, Columbia, Maryland) was used for data collection and analysis.

On each day of analysis, enough Tazocin lyophilized powder (Wyeth Canada; 3.375-g vial, lot B83227, expiry October 2008) was accurately weighed out to prepare a solution with concentration of about $1.15 \mathrm{mg} / \mathrm{mL}$ in HPLC-grade water.

\section{Physical Tests}

The $\mathrm{pH}$ of all samples was recorded on days $0,14,17,21$, 24,28 , and 31 using a calibrated $\mathrm{pH}$ meter. The instrument was calibrated on each day, before the $\mathrm{pH}$ measurements were obtained, using buffers with known $\mathrm{pH}$ of 4.00 and 7.00. To be within equipment specifications, the efficiency of the meter had to be $100 \% \pm 5 \%$.

Colour and clarity were monitored at each time point by viewing a sample from each bag under $4 \times$ magnification with illumination. These samples were observed against a black background for particulate matter and against a white background for colour change.

\section{Data and Statistical Analysis}

Relative standard deviation, resolution factors, and tailing factors were calculated using formulas taken from USP (United States Pharmacopia) 29.7 The linearity of the standard curve $\left(R^{2}\right)$ was assessed using the least mean-squared method. The concentrations of both tazobactam and piperacillin were calculated using the equation for each drug derived from the standard curve performed on the day of analysis.

\section{RESULTS}

\section{Degradation and Assay Validation}

Analysis of the acidic, oxidized, and heated samples showed no signs of interference of degradation products with either the tazobactam or piperacillin peaks. The tazobactam had degraded to $33 \%$ and the piperacillin to $44 \%$ of the original concentrations in the acidic sample; however, none of the new peaks that appeared between the tazobactam and piperacillin parent peaks interfered with analysis. Over the

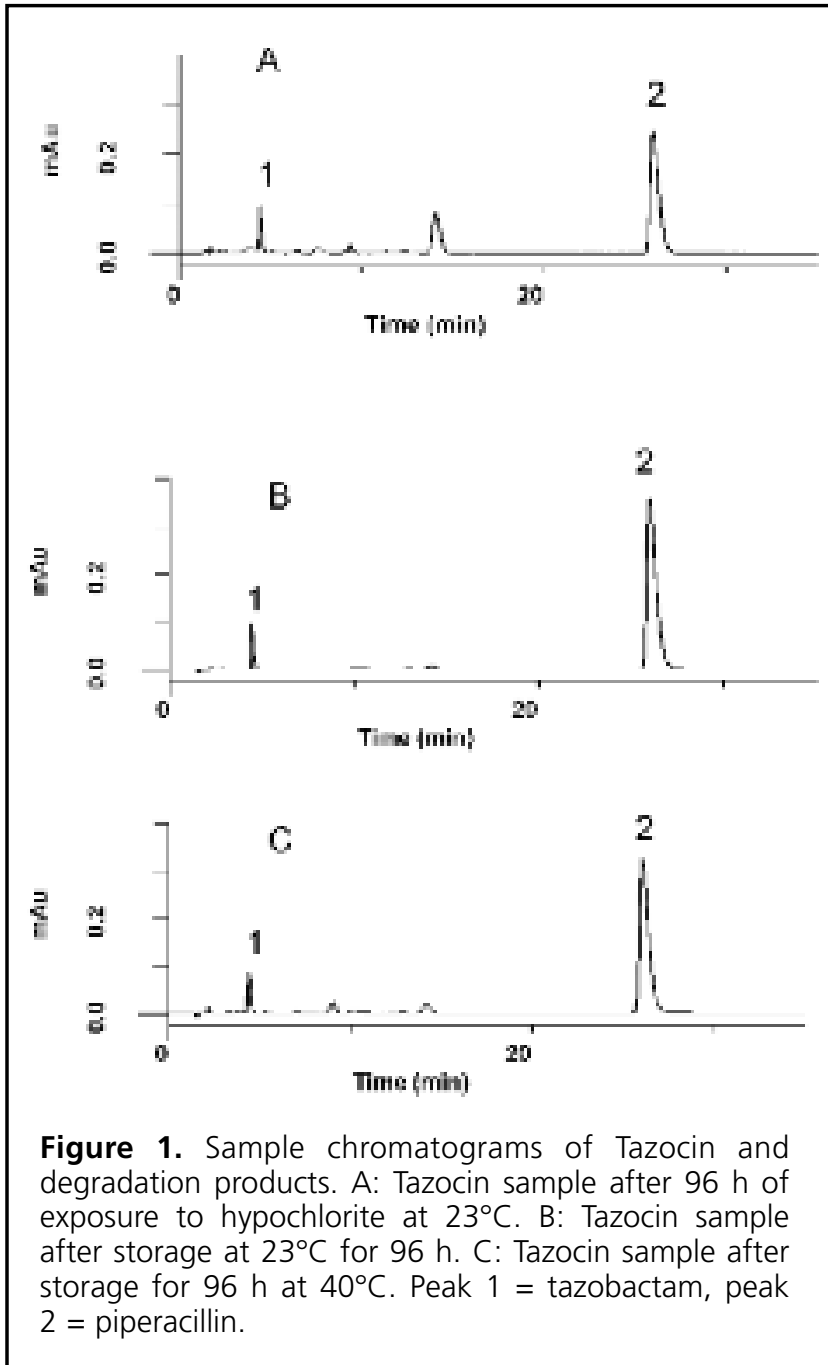


96-h study period, the oxidized sample also produced several peaks that eluted between the tazobactam and piperacillin peaks, but none of these interfered with the parent peaks (Figure 1A). There was little change in the concentrations of tazobactam and piperacillin after storage at $23^{\circ} \mathrm{C}$ for $96 \mathrm{~h}$ (Figure 1B). The heat-degraded sample produced some degradation peaks similar to those of the oxidized sample and some different ones, but in different concentrations, over $96 \mathrm{~h}$ of heating (Figure 1C). None of the degradation peaks interfered with either parent compound.

Standard curves for tazobactam and piperacillin were linear over the study concentrations. The reproducibility of the assay was measured as intraday coefficients of variance of $0.77 \%$ for tazobactam and $1.20 \%$ for piperacillin, whereas the interday coefficients of variance were $1.44 \%$ (slope) and $3.02 \%$ (average area ratios) for tazobactam and $1.22 \%$ (slope) and $2.89 \%$ (average area ratios) for piperacillin. The accuracy was $100.5 \% \pm 1.00 \%$ for tazobactam and $100.3 \% \pm 1.08 \%$ for piperacillin. The tazobactam sensitivity was $26 \mathrm{ng}$, and the piperacillin sensitivity was $200 \mathrm{ng}$.
All parent peaks from the degradation study were pure, as determined by spectral overlays and UV multiwavelength analysis. Relative standard deviation values were less than $2.0 \%$. Resolution and tailing factors were determined before the samples were run and were greater than 6.0 and less than 2.0 , respectively.

\section{Chemical Stability}

The average percentage of initial concentration remaining for all time points for the 4 combinations of drug concentration and diluent are summarized in Tables 1 to 4 . For both initial concentrations of the drug $(22.5$ and $90 \mathrm{mg} / \mathrm{mL})$, prepared in either diluent (D5W or NS), the measured concentration remained above $95 \%$ after 14,21 , or 28 days of storage at $5^{\circ} \mathrm{C}$ with protection from light. After an additional $72 \mathrm{~h}$ at $23^{\circ} \mathrm{C}$ with exposure to light (after each refrigerated storage period), the concentrations in all concentration-diluent combinations remained above 94\%. For each concentration-diluent combination, there was a slight decrease (by 3\%-4\%) in concentration after the additional $72 \mathrm{~h}$ storage

Table 1. Stability of Tazocin $22.5 \mathrm{mg} / \mathrm{mL}^{*}$ in D5W in PVC bags

\begin{tabular}{lcc} 
& \multicolumn{2}{c}{ Drug; \% of Initial Concentration Remainingt‡ } \\
\cline { 2 - 3 } Conditions and Study Day & Tazobactam & Piperacillin \\
\hline Initial concentration $(\mathrm{mg} / \mathrm{mL})$ & $2.7 \pm 0.05$ & $21.4 \pm 0.40$ \\
Day 14§ & $100.3 \pm 2.9$ & $102.3 \pm 3.0$ \\
Day 17\| & $97.5 \pm 1.9$ & $99.1 \pm 2.2$ \\
Day 21§ & $99.5 \pm 1.5$ & $100.9 \pm 1.6$ \\
Day 24\| & $96.4 \pm 2.7$ & $100.0 \pm 2.3$ \\
Day 28§ & $99.4 \pm 1.1$ & $101.9 \pm 1.0$ \\
Day 31\| & $97.6 \pm 1.4$ & $100.7 \pm 1.5$
\end{tabular}

$\mathrm{D} 5 \mathrm{~W}=5 \%$ dextrose in water, $\mathrm{PVC}=$ polyvinylchloride.

*Tazobactam $2.5 \mathrm{mg} / \mathrm{mL}$ and piperacillin $20.0 \mathrm{mg} / \mathrm{mL}$.

tMean \pm standard deviation $(n=6)$.

$\neq$ Except where indicated otherwise

$\S$ Samples stored at $5^{\circ} \mathrm{C} \pm 3^{\circ} \mathrm{C}$ with protection from light.

IISamples stored at $23^{\circ} \mathrm{C} \pm 3^{\circ} \mathrm{C}$ for an additional $72 \mathrm{~h}$ with exposure to light.

Table 2. Stability of Tazocin $90 \mathrm{mg} / \mathrm{mL}^{*}$ in D5W in PVC bags

\begin{tabular}{lcc} 
& \multicolumn{2}{c}{ Drug; \% of Initial Concentration Remainingt¥ } \\
\cline { 2 - 3 } Conditions and Study Day & Tazobactam & Piperacillin \\
\hline Initial concentration $(\mathrm{mg} / \mathrm{mL})$ & $10.9 \pm 0.20$ & $86.4 \pm 1.52$ \\
Day 14§ & $100.5 \pm 1.1$ & $102.5 \pm 2.1$ \\
Day 17\| & $100.2 \pm 1.1$ & $101.5 \pm 1.8$ \\
Day 21§ & $102.5 \pm 1.8$ & $103.8 \pm 1.6$ \\
Day 24\| & $99.7 \pm 1.8$ & $99.2 \pm 1.8$ \\
Day 28§ & $100.9 \pm 1.6$ & $101.7 \pm 1.4$ \\
Day 31\| & $98.8 \pm 1.7$ & $99.6 \pm 1.9$
\end{tabular}

$\mathrm{D} 5 \mathrm{~W}=5 \%$ dextrose in water, $\mathrm{PVC}=$ polyvinylchloride.

*Tazobactam $10.0 \mathrm{mg} / \mathrm{mL}$ and piperacillin $80.0 \mathrm{mg} / \mathrm{mL}$.

tMean \pm standard deviation $(n=6)$.

\#Except where indicated otherwise

$\S$ Samples stored at $5^{\circ} \mathrm{C} \pm 3^{\circ} \mathrm{C}$ with protection from light.

IISamples stored at $23^{\circ} \mathrm{C} \pm 3^{\circ} \mathrm{C}$ for an additional $72 \mathrm{~h}$ with exposure to light. 
Table 3. Stability of Tazocin $22.5 \mathrm{mg} / \mathrm{mL}^{*}$ in NS in PVC bags

\begin{tabular}{|c|c|c|}
\hline \multirow[b]{2}{*}{ Conditions and Study Day } & \multicolumn{2}{|c|}{ Drug; $\%$ of Initial Concentration Remainingt‡ } \\
\hline & Tazobactam & Piperacillin \\
\hline Initial concentration (mg/mL) & $2.6 \pm 0.02$ & $20.7 \pm 0.19$ \\
\hline Day $14 \S$ & $104.2 \pm 0.8$ & $106.7 \pm 2.4$ \\
\hline Day 17\| & $104.8 \pm 1.0$ & $107.5 \pm 1.1$ \\
\hline Day $21 \S$ & $105.5 \pm 1.7$ & $107.5 \pm 1.7$ \\
\hline Day 24\| & $102.7 \pm 2.0$ & $102.1 \pm 1.9$ \\
\hline Day $28 \S$ & $104.8 \pm 1.5$ & $106.2 \pm 1.0$ \\
\hline Day 31\| & $99.5 \pm 0.5$ & $102.2 \pm 0.5$ \\
\hline
\end{tabular}

$\mathrm{NS}=$ normal saline $(0.9 \% \mathrm{NaCl}), \mathrm{PVC}=$ polyvinylchloride

*Tazobactam $2.5 \mathrm{mg} / \mathrm{mL}$ and piperacillin $20.0 \mathrm{mg} / \mathrm{mL}$.

+Mean \pm standard deviation $(n=6)$.

$\neq$ Except where indicated otherwise

$\S$ Samples stored at $5^{\circ} \mathrm{C} \pm 3^{\circ} \mathrm{C}$ with protection from light.

\|Samples stored at $23^{\circ} \mathrm{C} \pm 3^{\circ} \mathrm{C}$ for an additional $72 \mathrm{~h}$ with exposure to light.

Table 4. Stability of Tazocin $90 \mathrm{mg} / \mathrm{mL}^{*}$ in NS in PVC bags

\begin{tabular}{lcc} 
& Drug; \% of Initial Concentration Remainingt‡ \\
\cline { 2 - 3 } Conditions and study day & Tazobactam & Piperacillin \\
\hline Initial concentration $(\mathrm{mg} / \mathrm{mL})$ & $11.6 \pm 0.13$ & $89.9 \pm 1.40$ \\
Day 14§ & $97.3 \pm 1.2$ & $100.1 \pm 1.3$ \\
Day 17\| & $97.2 \pm 1.9$ & $99.7 \pm 1.5$ \\
Day 21§ & $95.8 \pm 1.2$ & $98.7 \pm 1.2$ \\
Day 24\| & $96.4 \pm 1.6$ & $99.3 \pm 1.7$ \\
Day 28§ & $96.3 \pm 1.5$ & $99.0 \pm 1.4$ \\
Day 31\| & $94.6 \pm 1.6$ & $98.4 \pm 1.8$
\end{tabular}

NS = normal saline $(0.9 \% \mathrm{NaCl})$, PVC = polyvinylchloride.

*Tazobactam $10.0 \mathrm{mg} / \mathrm{mL}$ and piperacillin $80.0 \mathrm{mg} / \mathrm{mL}$

+Mean \pm standard deviation $(n=6)$.

\#Except where indicated otherwise

$\S$ Samples stored at $5^{\circ} \mathrm{C} \pm 3^{\circ} \mathrm{C}$ with protection from light.

IISamples stored at $23^{\circ} \mathrm{C} \pm 3^{\circ} \mathrm{C}$ for an additional $72 \mathrm{~h}$ with exposure to light.

at $23^{\circ} \mathrm{C}$ with exposure to light. There appeared to be no difference in stability related to the diluent used.

\section{Physical Compatibility}

The $\mathrm{pH}$ of all solutions remained within the range of 5.50 to 6.08 over the course of the study. All solutions remained clear and colourless throughout the study.

\section{DISCUSSION}

The measured concentration of both drugs in either D5W or NS remained above $95 \%$ of the initial concentration after 28 days of storage at $5^{\circ} \mathrm{C}$ with protection from light. The difference in the concentrations $(22.5 \mathrm{mg} / \mathrm{mL}$ versus $90 \mathrm{mg} / \mathrm{mL}$ ) seemed to have no effect on the shelf life. Storage at $23^{\circ} \mathrm{C}$ for an additional $72 \mathrm{~h}$ caused a $3 \%-4 \%$ decrease in the concentrations of both tazobactam and piperacillin.

It has previously been reported ${ }^{4}$ that $B$-lactam antibiotics are generally most stable between $\mathrm{pH} 6$ and 7 . Rigge and Jones ${ }^{4}$ found that unbuffered solutions in NS had an initial $\mathrm{pH}$ of 5.3, with a subsequent decrease in $\mathrm{pH}$ to 4.5 over time, which led these authors to suggest a shorter expiry date. Inclusion of EDTA and sodium citrate in the reformulated Tazocin might explain why, in the present study, the $\mathrm{pH}$ never dropped below 5.50; this in turn might contribute to the longer shelf life.

Tazocin solutions at initial concentration of 22.5 or 90 $\mathrm{mg} / \mathrm{mL}$ in either D5W or NS, prepared and stored in PVC bags, were chemically stable for up to 28 days at $5^{\circ} \mathrm{C}$ with protection from light followed by $72 \mathrm{~h}$ at $23^{\circ} \mathrm{C}$ with exposure to light.

\section{References}

1. Tazocin monograph. In: E-CPS. Ottawa (ON): Canadian Pharmacists Association; [revised 2007 May 24; cited 10 Oct 2006]. Available from: https://www.e-therapeutics.ca/ (subscription required to access content).

2. Moon YSK, Chung KC, Chin A, Gill MA. Stability of piperacillin sodium-tazobactam sodium in polypropylene syringes and polyvinyl chloride bags. Am J Health Syst Pharm 1995;52(9):999-1001.

3. Hecq JD, Berlage V, Vanbeckbergen D, Jamart J, Galanti L. Effects of freezing, long-term storage, and microwave thawing on the stability of piperacillin plus tazobactam in 5\% dextrose for infusion. Can J Hosp Pharm 2004;57(5):276-282.

4. Rigge DC, Jones MF. Shelf lives of aseptically prepared medicines—stability of piperacillin/tazobactam in PVC and non-PVC bags. J Pharm Biomed Anal 2005;39(4):339-343. 
5. Mathew M, Das Gupta V, Bethea C. Stability of piperacillin sodium in the presence of tazobactam sodium in 5\% dextrose and normal saline injections. J Clin Pharm Ther 1994;19(6):397-399.

6. Desai NR, Shah SM, Cohen J, McLaughlin M, Dalal HR. Zosyn (piperacillin/tazobactam) reformulation: expanded compatibility and coadministration with lactated Ringer's solutions and selected aminoglycosides. Ther Clin Risk Manag 2008;4(2):303-314.

7. General chapter 1010: Analytical data-interpretation and treatment. In: US Pharmacopeia 29 and National Formulary 24. Rockville (MD): US Pharmacopeial Convention; [cited 11 Jan 2007]. Available from: http://www.uspnf.com (subscription required to access content).

Ronald F Donnelly, MSc(Chem), BSc(Pharm), is Product Development Pharmacist, Department of Pharmaceutical Sciences, The Ottawa Hospital (Civic Campus), Ottawa, Ontario.

\section{Address correspondence to:}

Ron Donnelly

Department of Pharmacy

The Ottawa Hospital

1053 Carling Avenue

Ottawa ON

K1Y 4E9

e-mail: rdonnelly@ottawahospital.on.ca

\section{Acknowledgement}

This study was supported by an unrestricted grant from Baxter Corporation and Wyeth Canada.

\section{The $C J H P$ now available online}

The Canadian Society of Hospital Pharmacists (CSHP) is pleased to announce the launch of a new online hosting platform for the Canadian Journal of Hospital $\%$ marmocy $(C) / H)$,

Our members and $C: H P$ subscribers have made it clear that an easy-to-use and fully searchable electronic version of the $C I M P$ is important to them. The new $C I I P$ website uses Open Journal Systems (OJS) software to bring you each issue in a clear and readable electronic format.

The intuitive OJS platform offers full searching of the CIIIP archives that are available to date Currently, the $C J H P$ online has a complete archive of issues from 2000 to the present, with plans to add more issues from earlier volumes in the future

To celebrate this milestone, CSHP is offering free open access to all of the CIHP archives and current issues for the rest of 2009 ! After this year, CSHP nembers and $C . J H P$ subscribers will continue to have free access to the electronic $C . / H^{3}$, but there will be a charge for other users. We encourage members and subscribers to spread the word about this free trial, especially to any colleagues who are not yet members of CSHP or who do not subscribe to the $C J H P$.

The new electronic $C / H /$ ' is available at htto / $/$ www cjhp-online ca $A 11$ users will need to register to use the OJS system using the "Regrister" link in the top menu bar.

If you have any questions, please feel free to contact Sonya Heggart, CSHP's Publications Administrator, by phone at 613-736-9733 ext. 228 or email at shegrart@eshp.ca. 